\title{
IAMJ
}

INTERNATIONAL

AYURVEDIC

MEDICAL JOURNAL

ISSN: 23205091

Impact Factor: 5.344

\section{AN OBSERVATIONAL STUDY TO ASSESS THE STRUCTURAL CHANGES IN JANUSANDHI OF PATIENTS PRESENTING WITH KNEE JOINT PAIN}

\section{$\underline{\text { Anjana }}^{1}$, Pralhad D Subbannavar ${ }^{2}$}

${ }^{1}$ Final Year PG Scholar, Department of Shareera Rachana, Sri Dharmasthala Manjunatheswara College of Ayurveda, Udupi, Karnataka, India

${ }^{2}$ Associate Professor, Department of Shareera Rachana, Sri Dharmasthala Manjunatheswara College of Ayurveda, Udupi, Karnataka, India

Corresponding Author: dranjana.ayu@gmail.com

\section{https://doi.org/10.46607/iamj2408102020}

(Published online: October 2020)

Open Access

(C) International Ayurvedic Medical Journal, India 2020

Article Received: 30/09/2020 - Peer Reviewed: 03/10/2020 - Accepted for Publication: 04/10/2020

Check for updates

\section{ABSTRACT}

Objectives: To observe the structural changes occurring in patients presenting with knee joint pain., To analyse range of motion and tissue involvement in the knee joint pain. Methods 100 patients having history of knee joint pain has been selected for the study from OPD and IPD of S.D.M Ayurveda hospital Udupi. Case Proforma was prepared to assess the knee joint pain. Assessment of range of movement has been done with Goniometer. Structural changes in knee joint pain was assessed with help of X-ray or MRI. Result: In this study $50 \%$ of patients had knee pain due to the degenerative changes in joint either due to aging or hormonal issues or autoimmune diseases like arthritis. Majority of structural changes were observed in the medial femorotibial compartment showing $92 \%$ having presence of osteophytes and $80 \%$ having joint space narrowing. 59\% patients were diagnosed with osteoarthritis showing definitive degenerative changes. Range of movement was decreased in cases having structural changes and in 12\% cases the range was observed between 80-70 degree which had gross changes in the structures. Conclusion: Radiological findings are essential for assessing the anatomical structures and plays major role in understanding the pathology. The examination of range of movement will provide an idea about the 
joint activity and when compared with the structural changes; can provide a clear idea to the physician in planning the treatment

Keywords: Knee Joint, Anatomical structures, Sedentary

\section{INTRODUCTION}

Knee joint is a complex synovial joint of the body as it is the result of three joints in one. This massive joint carries severe stress and strength of the joint depends on ligaments and muscles ${ }^{1}$.It is the most remarkable joint by any engineering standards and most heavily stressed joint in the body ${ }^{2}$; it is imperfectly protected from the twists and strains of weight bearing ${ }^{3}$. Among musculoskeletal disorders, knee joint pathologies have got the prevalence of $10 \%{ }^{4}$. The Sankhya \& Prakara of Janusandhi is given as 2 in number and Kora Sandhi according to Susruta Samhita ${ }^{5}$ \& Astanga Samgraha ${ }^{6}$ and Pramana is given in Charaka Samhita $^{7}$ as 4 Angula in length and 16 Angula in circumference. Knee Joint is a modified Hinge joint involving 3 bones: the femur, the tibia and the patella with 3 articular surfaces. The medial and lateral menisci cushion the action of femur on tibia. It is dependent on ligaments to hold its articulating bones in place along with this lever action of femur on tibia and lack of padding from fat or muscle, makes the knee highly vulnerable to injury ${ }^{8}$. In today's era due to sedentary lifestyle and severe decline in physical activity, several sports injuries, improper and untimely food intake will affect knee joint. The overall prevalence of knee pain is $46.2 \%$ in the world and this accounts for the necessity to study the anatomical structures affected in knee pain

\section{Material and Methods}

- Case proforma was prepared for 100 patients from IPD/OPD of SDM College of Ayurveda, Udupi having knee joint pain.

- Range of Movement was done using Goniometer.

- Structural changes were identified using either of radiological observations like X- Ray or MRI

\section{Criteria of The Study:}

Inclusion Criteria: All the patients irrespective of gender having signs and symptoms of knee joint pain.

Exclusion Criteria: Congenital anomalies

\section{RESULTS \& DISCUSSION}

With the help of detailed Case proforma, observation in structural changes was noted $\&$ is being discussed henceforth. Maximum number of patients were observed in 55 to 65 years of age group. Age is a factor in causing knee joint pathologies and as age advances structural changes occurs in the joint causing degenerative disease. $64 \%$ of the patients were females; the universal data also says the prevalence of knee joint diseases are more seen in females. $64 \%$ of patients registered in the study were having a sedentary lifestyle, among them most were housewife who are accustomed to moderate work. The sedentary type of lifestyle, having less exercises leading to decrease in the joint movement will increase the stiffness, and degeneration of the joint. $75 \%$ of patients had mixed diet. As most of the patients were residents of coastal area, they were habituated to non vegetarian diet. Consumption of Jalaja Mamsa, and having more of Katu, Tiktha Rasa Yukta Ahara is a Nidana for Vata Prakopa causing knee pain. 50\% of the patients were having knee pain caused by degenerative changes occurring due to increase of age or due to hormonal issues or either due to autoimmune diseases like arthritis. The role of thyroid hormone in calcium metabolism is a proven fact and it affects the bone replacement. In $16 \%$ of patients, cause of knee pain was due to obesity. In obese persons excess weight increases joint loading resulting in deleterious effect on the weight bearing joints and contributes to negative effects related to inflammation. The chance of having multiple causes which can lead to knee joint pain should also be considered. $61 \%$ of the patients were having bilateral knee joint pain, rest 23\% had right side knee joint pain and $16 \%$ with left side knee joint pain. In $96 \%$ patients, tenderness was observed during palpation, this indicates the importance of assessing the structural changes in a patient to infer the anatom- 
ical structures involved in causing the pathology. $69 \%$ of the patients had crepitus while palpation of the knee joint. The presence of crepitus indicates the progression in degeneration of the knee joint and the importance of assessing structural changes. $95 \%$ of patients experienced pain while flexing the knee joint., $86 \%$ of patients experienced pain while extension of the knee joint.

Range of Movement: Assessed with help of Goniometer.

The normal range of motion of knee joint in flexion is 130-125 degree. In this study,33\% of patients had range of movement between $110-100$ degree. The patients with gross structural changes had decreased range of movement; between 80-70 degree i.e. in $12 \%$ cases. Patients having inflammatory condition also had a decreased range of movement ranging between 90-80 degree i.e. in 19\% of cases. The range of movement is decreased by degenerative structural changes due to increase in age, due to diseases like osteoarthritis, rheumatoid arthritis etc. and also due to injury to menisci or ligaments in case of knee joint.

Structural Changes: accessed with help of X -Ray / MRI

\section{Osteophytes:}

In $92 \%$ patients, osteophytes were seen in Medial femorotibial Compartment, among that $43 \%$ had gross amount and $49 \%$ had mild osteophytes. $88 \%$ had osteophytes in lateral femorotibial and $64 \%$ had osteophytes in patellofemoral compartment. Osteophytes are formed due to revascularization of remaining cartilage and capsular traction. The weight bearing axis pass through the medial femorotibial compartment and due to this more degenerative change are seen in this compartment.

Subchondral Sclerosis: In 14\% cases severe sclerosis had been found. Sclerosis is due to increased cellularity and bone deposition.

Subchondral cyst: In 44\% subchondral cyst was seen in medial femorotibial compartment and 39\% had subchondral cyst in lateral femorotibial compartment. Subchondral cysts are formed due to the synovial intrusion into the bone and mostly seen in osteoarthritic cases.
Joint Space: In $80 \%$ cases, space narrowing was seen in medial femorotibial compartment and $67 \%$ had narrowing in lateral femorotibial compartment. Joint space narrowing indicates the degeneration of the cartilage that keep the bones apart, resulting in joint pain, joint stiffness leading to decrease in range of motion. Increased joint space was seen in 3 cases, having inflammatory pathologies occurring due to the accumulation of fluid in or around the joint, mainly seen in inflammatory pathologies.

Axis Deviation: In $45 \%$ of cases axis deviation was present. Weight bearing axis passes through medial femorotibial compartment and as the degeneration progresses the axis will be altered.

\section{Diseases:}

Among the 100 patients, 59\% were affected with osteoarthritis, $15 \%$ with rheumatoid arthritis, $9 \%$ due to hormonal issues and various other pathologies, 5\% had osteoporosis, $4 \%$ had meniscal injury and $8 \%$ had ligament tear. Majority of patients were having knee pain due to Osteoarthritis \& had gradual onset of pain, decreased range of movement and degenerative changes in the anatomical structures including presence of osteophytes, sclerosis and joint space narrowing. Slight relief in symptoms were observed after daily activities. Patients with Rheumatoid arthritis had knee pain associated with intermittent swelling, morning stiffness, decrease in range of motion and changes in blood parameter showing positive RA factor. In these cases, major structural changes were observed in the knee joint. $9 \%$ of patients had hormonal issues like hypothyroidism, which will cause changes in joint cavity and resulting in knee joint pathology. In few cases, the injuries to knee joint were due to fall, sports injury or accidents, resulting in meniscal or ligament tear, which was confirmed by MRI.

\section{CONCLUSION}

Janu Sandhi is a Kora Sandhi, which can be correlated to Hinge variety of Synovial joint. Sedentary lifestyle, age and diet play an important role in increasing the structural changes in knee joint. The osteophytes are the radiographic feature that associates best with knee pain. Radiographic assessment of both tibiofem- 
oral and patellofemoral compartment should be done. The weight bearing axis pass through Medial Femorotibial compartment, so it may be the reason for more structural changes seen in that compartment. The examination of range of movement and assessment of various structures in knee joint will provide the clinician a clear idea about the joint activity and also planning the treatment.

\section{REFERENCES}

1. G.J. Romanes. Cunningham's Manual Of Practical Anatomy. (15 $5^{\text {th }}$ edition). New York: Oxford Publications; Reprint 1999. P. 214. (Upper and Lower Limbs; Vol 1).

2. John Ebenezer. Textbook of Orthopaedics. (3 $3^{\text {rd }}$ edition). New Delhi: Jaypee brothers Medical Publishers; 2006. P. 219.

3. E.L Trickey. Injuries of the knee. In: J. N. Wilson, editor. Watson- Jones Fractures and Joint Injuries. (7th edition). New Delhi: Elsevier India Pvt Limited; Reprint 2013. P. 913.

4. Brian R Walker, Nicki R. Colledge, Stuart H. Ralston, Ian D. Penman. Davidson's Principles \& Practice of Medicine. (22nd edition). China: Churchill Living stone; 2014. P. 1060.

5. Vaidya Jadavji Trikamji, editor. Commentary NibandaSangraha of Dalhana of Sushrutha Samhita of Sushrutha, Shareera Sthana; Shareerasankhya vyakaranashareeram: Chapter 5, Verse 26-27. Varanasi: Chaukambha Orientalia, 2002; P.366-7.

6. Dr Shiva Prasad Sharma, editor. Commentary Sasilekha Sanskrit of Indu of Astangasamgrahas of Vriddha Vagbhata, Shareera Sthana; Angavibhagamshareeram: Chapter 5, Verse 66-70. Varanasi: Chaukambha Sanskrit Series Office, Reprint 2016; P. 306.

7. Vaidya Jadavji Trikamji, editor. Commentry Ayurvediya Deepika of Chakrapanidatta of Charaka Samhita of Agnivesa, Charaka, Dridhabala, Vimana Sthana; Rogabhishagjatheeyamvimanam: Chapter 8, Verse 117. Varanasi: Chaukhamba Prakashan; Reprint 2013; P. 279 .

8. Lynn S. Buckley, Peter G Szilagyi. Bates Guide to Physical Examination and History taking. (10th edition). New Delhi: Wolter's Kluwer (India) Pvt. Limited; Reprint 2009. P. 625.

\section{Source of Support: Nil \\ Conflict of Interest: None Declared}

How to cite this URL: Anjana P \& Pralhad D Subbannavar: An Observational Study To Access The Structural Changes In Janusandhi Of Patients Presenting With Knee Joint Pain. International Ayurvedic Medical Journal \{online\} 2020 \{cited October, 2020 $\quad$ Available from: http://www.iamj.in/posts/images/upload/4732_4735.pdf 